\title{
Synthetic Control of the Photoluminescence Stability of Organolead Halide Perovskites
}

\author{
Daniel J. Freppon, ${ }^{1,2}$ Long Men, ${ }^{1,2}$ Ujjal Bhattacharjee, ${ }^{1,2}$ Bryan A. Rosales, ${ }^{1}$ Feng Zhu, ${ }^{1}$ Jacob W. \\ Petrich, ${ }^{1,2}$ Emily A. Smith, ${ }^{* 1,2}$ and Javier Vela ${ }^{*, 1,2}$ \\ ${ }^{1}$ Department of Chemistry, Iowa State University. \\ ${ }^{2}$ Ames Laboratory, Ames, Iowa 50011. \\ *Corresponding author: Emily A. Smith, e-mail: esmith1@iastate.edu; Javier Vela, e-mail: \\ vela@iastate.edu \\ Received July $7^{\text {th }}$, 2018; Accepted April 9 ${ }^{\text {th }}, 2019$. \\ DOI: http://dx.doi.org/10.29356/jmcs.v63i3.623
}

\begin{abstract}
An optimized synthetic procedure for preparing photostable nanocrystalline methylammonium lead halide materials is reported. The procedure was developed by adjusting the lead halide to methylammonium/octylammonium halide precursor ratio. At a high precursor ratio (1:3), a blue-shifted photoinduced luminescence peak is measured at $642 \mathrm{~nm}$ for $\mathrm{CH}_{3} \mathrm{NH}_{3} \mathrm{PbI}_{3}$ with 0.01 to $12 \mathrm{~mJ}$ pulsed-laser irradiation. The appearance of this peak is reversible over $300 \mathrm{~min}$ upon blocking the irradiation. In order to determine if the peak is the result of a phase change, in situ x-ray diffraction measurements were performed. No phase change was measured with an irradiance that causes the appearance of the photoinduced luminescence peak. Luminescence microscpectroscopy measurements showed that the use of a lower precursor ratio (1:1.5) produces $\mathrm{CH}_{3} \mathrm{NH}_{3} \mathrm{PbI}_{3}$ and $\mathrm{CH}_{3} \mathrm{NH}_{3} \mathrm{PbBr}_{3}$ perovskites that are stable over 4 min of illumination. Given the lack of a measured phase change, and the dependence on the precursor ratio, the photoinduced luminesce peak may derive from surface trap states. The enhanced photostability of the resulting perovskite nanocrystals produced with the optimized synthetic procedure supports their use in stable optoelectronic devices.
\end{abstract}

Keywords: surface traps, nanocrystalline perovskites, photostability, single nanocrystal analysis, synthetic optimization, optoelectronics.

Resumen. Se reporta un proceso sintético optimizado para preparar materiales haluros de metilamonioplomo nanocristalinos fotoestables. El proceso fue desarrollado ajustando la relación entre los precursores de haluro de metilamonio y haluro de octilamonio. Con una relación de precursores alta (1:3), un pico luminiscente desviado al azul a $642 \mathrm{~nm}$ fue detectado para $\mathrm{CH}_{3} \mathrm{NH}_{3} \mathrm{PbI}_{3}$ con irradiación de láser de pulso entre 0.01 y $12 \mathrm{~mJ}$. La aparición de éste pico es reversible hasta por 300 min después de cesar la irradiación. Para determinar si éste pico se debe a una transición de fase, se hicieron mediciones de difracción de rayos- $X$ in situ. Ningún cambio de fase fue detectado con niveles de irradiación a los cuales se observa el pico luminiscente. Mediciones luminiscentes macroespectroscópicas muestran que con una relación de precursores más baja (1:1.5) se producen perovskitas $\mathrm{CH}_{3} \mathrm{NH}_{3} \mathrm{PbI}_{3}$ y $\mathrm{CH}_{3} \mathrm{NH}_{3} \mathrm{PbBr}_{3}$ que son estables hasta con 4 min de iluminación. Dado que no se observa un cambio de fase, y la dependencia sobre la relación de precursores, el pico luminiscente generado bajo iluminación podría derivarse de estados trampa de superficie. La fotoestabilidad incrementada de los nanocristales de perovsita obtenidos por el procedimiento sintético optimizado ayudan a su aplicación en dispositivos optoelectrónicos más estables.

Palabras clave: trampas de superficie, perovskitas nanocristalinas, fotoestabilidad, análisis de nanocristal individual, optimización sintética, optoelectrónica 


\section{Introduction}

Organolead halide perovskite semiconductors of general composition $\mathrm{RPbX}_{3}(\mathrm{R}=$ organic monocation, such as $\mathrm{CH}_{3} \mathrm{NH}_{3}{ }^{+} ; \mathrm{X}=$ halide, such as $\mathrm{I}^{-}$or $\mathrm{Br}^{-}$) have drawn attention as both photovoltaic $[1,2]$ and optoelectronic [3] materials. Broad light absorption and long carrier diffusion lengths make perovskites ideal light harvesters [4]. The certified power conversion efficiency of perovskite solar cells surged from $3.8 \%$ to over $22 \%$ in the last 8 years [5-10]. In spite of these many advantages, organometal halide perovskites suffer from instability against moisture, heat and light [11-13]. A deeper understanding of the fundamental physical and chemical behavior of perovskites could help in mitigating these instability issues, thus enabling their implementation and deployment into many energy technologies $[14,15]$.

Efforts to improve the physical and chemical properties of perovskites have focused primarily on tuning their composition or dimensionality $[16,17]$. Compositional and dimensional control are useful in tuning the bandgap energies of some perovskite materials $[18,19]$. Partial substitution with long alkylammonium cations leads to low dimensional perovskites [20-22], some of which exhibit enhanced moisture stability. Control of optoelectronic properties through mixing cations and halides has been widely exploited in enhancing the power conversion efficiency of perovskite solar cells [14, 23-25]. Compositional variants of halide perovskites have bandgap and luminescence energies that cover the entire visible spectrum [9, 26-28]. Halide substitution also leads to enhanced stability, as $\mathrm{CH}_{3} \mathrm{NH}_{3} \mathrm{PbI}_{3}$ solar cells doped with $\mathrm{Br}$ show long-lasting resistance against humidity $[29,30] . \mathrm{CH}_{3} \mathrm{NH}_{3} \mathrm{PbBr}_{3}$ displays lower sensitivity to concentrated sunlight compared to $\mathrm{CH}_{3} \mathrm{NH}_{3} \mathrm{PbI}_{3}$ [31].

A few reports describe the unusual photophysical behavior of organometal halide perovskites, specifically a reversible shift in photoluminescence maximum $\left(\lambda_{\max }\right)$ under thermal and photochemical conditions [32-34]. Gottesman et al. observed a decrease in luminescence intensity and increase in the 108 $\mathrm{cm}^{-1}$ Raman band of $\mathrm{CH}_{3} \mathrm{NH}_{3} \mathrm{PbI}_{3}$ solar cells, and attributed these changes to slow photoinduced structural changes since the timescale of the change was not consistent with an electronic process [34]. Sadhanala and co-workers measured two absorption peaks in freshly-prepared, mixed-halide $\mathrm{CH}_{3} \mathrm{NH}_{3} \mathrm{~Pb}\left(\mathrm{Br}_{1-\mathrm{x}} \mathrm{I}_{\mathrm{x}}\right)_{3}$ perovskite films. A single absorption band, however, was measured after aging the film for 21 days [33]. Hoke et al. have also reported light-induced changes to the absorption and photoluminescence spectra of $\mathrm{CH}_{3} \mathrm{NH}_{3} \mathrm{~Pb}_{(}\left(\mathrm{Br}_{1-\mathrm{x}} \mathrm{I}_{\mathrm{x}}\right)_{3}$ perovskite films. They attribute these behaviors to reversible crystalline changes and trap states [32]. Structural defects and ion migration contribute to the notorious photocurrent hysteresis $[35,36]$ and specific quantum efficiency [37] that characterizes perovskite semiconductors and devices. Unusual photophysics that are caused by surface defects may become even more prominent in nanocrystalline perovskites [38].

Trap states in perovskites. $\mathrm{CH}_{3} \mathrm{NH}_{3} \mathrm{PbI}_{3}$ has a broad emission band and a high quantum yield of photoluminescence. The nature of the radiative decay channels and the spectral broadening mechanisms are largely determined by phonon coupling effects and defects or trap states [39]. Trap states are likely to occur at the surface of perovskite nanocrystals [38]. Vacancies, such as ionic defects like $\mathrm{Pb}^{+}, \mathrm{I}^{-}$, and $\mathrm{CH}_{3} \mathrm{NH}_{3}{ }^{+}$, can also form shallow trap states and reduce carrier lifetimes [40]. Strong covalency of the $\mathrm{Pb}$ cations and I anions lead to the formation of $\mathrm{Pb}$ dimers and iodide trimers, which are responsible for transition levels that can serve as recombination centers that reduce solar-cell performance [41]. Trap states increase the frequency of nonradiative recombination, which reduces the quantum yield [42]. Density-functional theory studies have revealed the unusual defect physics of $\mathrm{CH}_{3} \mathrm{NH}_{3} \mathrm{PbX}_{3}$ [41, 43-46]. For example, shallow point defects could explain in part the ultra-high open-circuit voltages of $\mathrm{CH}_{3} \mathrm{NH}_{3} \mathrm{PbBr}_{3}$ solar cells [46].

Synthetic conditions play an important role in the formation of trap states. For example, perovskites grown under high iodine concentrations are likely to have defects (lead atom substituted by iodide) and a high density of deep electronic traps (recombination centers) that cause short diffusion lengths and poor photovoltaic performance [47]. Supramolecular halogen bond complexation can passivate the under-coordinated iodine ions, which can reduce trap sites near the perovskite surface [48]. Lewis bases are used to passivate under-coordinated lead atoms, and treated perovskites exhibited reduced electron-hole recombination and consequently longer photoluminescence lifetimes [49]. Adding fullerene layers has also proven to be an effective way to passivate the charge trap states and get rid of photocurrent hysteresis $[35,50]$.

Building on our previous work [22], a systematic synthesis of photostable nanocrystalline $\mathrm{CH}_{3} \mathrm{NH}_{3} \mathrm{PbX}_{3}$ is demonstrated. Optimization of the $\mathrm{CH}_{3} \mathrm{NH}_{3} \mathrm{PbI}_{3}$ alkyl halide to lead halide precursor ratio, 
inhibited the appearance of a reversible photoinduced 630 -nm photoluminescence peak that may be derived from surface traps. Using an optimized synthetic procedure, luminescence of single $\mathrm{CH}_{3} \mathrm{NH}_{3} \mathrm{PbI}_{3}$ and $\mathrm{CH}_{3} \mathrm{NH}_{3} \mathrm{PbBr}_{3}$ nanocrystals was stable over 240 seconds with over $1 \times 10^{5} \mathrm{~W} / \mathrm{cm}^{2}$ irradiance. The reported optimized synthesis may be applicable to other organometal halide perovskites, for example those with mixed halide composition.

\section{Experimental}

\section{Materials}

Lead(II) bromide ( $\geq 98 \%$ ), N,N-dimethylformamide (DMF), lead(II) iodide (99\%), methylamine (33 $\mathrm{wt} \%$ in ethanol), $n$-octylamine (99\%), and toluene (anhydrous, 99.8\%) were purchased from Sigma-Aldrich. Hydrobromic acid (ACS, 47.0-49.0\%), hydroiodic acid (ACS, 55-58\%), and oleic acid (tech., 90\%) from AlfaAesar; diethyl ether from Baker; toluene (99.9\%) and acetonitrile (99.9\%) from Fisher. Materials were used as received unless specified otherwise.

\section{Synthesis}

Ammonium Halides. Dimensionality control is achieved using a bulky alkylammonium cation as a capping ligand. Hydrogen halides were prepared by a modified literature procedure [45]. Briefly, hydroiodic acid $(10 \mathrm{~mL}, 0.075 \mathrm{~mol})$ or hydrobromic acid $(8.6 \mathrm{~mL}, 0.075 \mathrm{~mol})$ was added to a solution of excess methylamine $(24 \mathrm{~mL}, 0.192 \mathrm{~mol})$ in ethanol $(100 \mathrm{~mL})$ at $0{ }^{\circ} \mathrm{C}$, and the mixture stirred at this temperature for 2 h. The sample was concentrated under vacuum, and the resulting powder dried under dynamic vacuum at $60^{\circ} \mathrm{C}$ for $12 \mathrm{~h}$ and recrystallized from ethanol. Both $n$-octylammonium iodide $\left(\mathrm{CH}_{3}\left(\mathrm{CH}_{2}\right)_{7} \mathrm{NH}_{3} \mathrm{I}\right)$ and $n$ octylammonium bromide $\left(\mathrm{CH}_{3}\left(\mathrm{CH}_{2}\right)_{7} \mathrm{NH}_{3} \mathrm{Br}\right)$ were washed repeatedly with diethyl ether and dried under dynamic vacuum before use.

Nanocrystalline $\mathbf{C H}_{3} \mathbf{N H}_{3} \mathbf{P b X} \mathbf{X}_{3}$. $\mathrm{PbX}_{2}(0.008 \mathrm{mmol}), \mathrm{CH}_{3} \mathrm{NH}_{3} \mathrm{X}(0.012 \mathrm{mmol})$ and $\mathrm{CH}_{3}\left(\mathrm{CH}_{2}\right)_{7} \mathrm{NH}_{3} \mathrm{X}$ $(0.012 \mathrm{mmol})$ were dissolved in a mixture of acetonitrile $(20 \mathrm{~mL})$ and DMF $(200 \mu \mathrm{L}) .4 \mathrm{~mL}$ of the resulting precursor solution was rapidly injected into toluene $(15 \mathrm{~mL})$ while stirring. After $24 \mathrm{~h}$ stirring at $20^{\circ} \mathrm{C}$, solids were isolated by centrifugation (10 min at $4000 \mathrm{rpm})$ and purified by washing with toluene $(5 \mathrm{~mL})$ followed by re-centrifugation.

\section{Structural Characterization}

X-ray diffraction (XRD) was collected on a Rigaku Ultima IV (40 kV, $44 \mathrm{~mA})$. A Cu KR source was used for radiation. A quartz sample holder was used as a substrate for drop-casted toluene solvated samples. Details of the in situ measurements were as previously reported [51]. Transmission Electron Microscopy (TEM) images were collected using a FEI Tecnai G2 F20 field-emission TEM capable of $200 \mathrm{kV}$ with a point-to-point resolution of less than $0.25 \mathrm{~nm}$ having a $0.10-\mathrm{nm}$ line-to-line resolution. Dilute solutions were prepared in toluene and 2 to 3 drops of each product were placed onto carbon-coated copper grids. TEM images were used to measure the particle dimensions and were processed using the ImageJ program. Typically, more than 100 particles were counted in each case. Uncertainties in all measurements are reported as standard deviations.

\section{Optical Characterization}

Solution-phase optical extinction (absorption plus scattering) spectra were collected using an Agilent $8453 \mathrm{UV} / \mathrm{Vis}$ spectrophotometer equipped with a photodiode array. Solvent absorption was subtracted from all spectra. Drop-casted solid films of each sample were measured using diffuse reflectance (SL1 Tungsten Halogen lamp (vis-IR), a SL3 Deuterium Lamp (UV), and a BLACK-Comet C-SR-100 Spectrometer). A Horiba-Jobin Yvon Nanolog scanning spectrofluorometer equipped with a photomultiplier detector was used to collect steady-state PL spectra. Quantum yields for each nanocrystalline perovskite were calculated by comparing luminescence intensities of Rhodamine 590 or 640 [52].

For the luminescence microspectroscopy of single nanocrystals, a DM IRBE microscope (Leica, Wetzlar, Germany) was employed. Monochromatic illumination with a $532 \mathrm{~nm}$ laser (Coherent, Santa Clara, 
CA) was used to excite $\mathrm{CH}_{3} \mathrm{NH}_{3} \mathrm{PbI}_{3}$, and a $488 \mathrm{~nm}$ Argon ion laser (Uniphase, San Jose, $\mathrm{CA}$ ) for $\mathrm{CH}_{3} \mathrm{NH}_{3} \mathrm{PbBr}_{3}$. An oil-immersion objetctive producing a spot with a $0.28 \pm 0.03 \mu \mathrm{m}$ diameter provided an excitation power density of $1.6 \times 10^{5} \mathrm{~W} \cdot \mathrm{cm}^{-2}$. PL was collected using a HoloSpec $\mathrm{f} / 1.8 \mathrm{i}$ spectrograph (Kaiser Optical Systems, Ann Arbor, MI, USA) equipped with a broad-range grating (HFG-650, Kaiser Optical Systems) and a charged-coupled device (CCD) (Newton 940, Andor Technology, Belfast, UK) with a collection binning time of $0.05 \mathrm{~s} .2400$ spectra were collected every 0.09873 seconds.

\section{Results and discussion}

\section{General Synthesis and Characterization}

Nanocrystalline organolead halide perovskites are prepared by dissolving (a) $\mathrm{PbX}_{2}$, (b) $\mathrm{CH}_{3} \mathrm{NH}_{3} \mathrm{X}$, and (c) $\mathrm{CH}_{3}\left(\mathrm{CH}_{2}\right)_{7} \mathrm{NH}_{3} \mathrm{X}(\mathrm{X}=\mathrm{I}$ or $\mathrm{Br})$ precursors in a polar solvent such as dimethyl formamide (DMF, $\left.\varepsilon=38.25\right)$ or acetonitrile $(\varepsilon=36.64)$, followed by quick injection into a less polar solvent such as toluene $(\varepsilon=2.379)$ as shown in Scheme 1 [22]. DMF, acetonitrile, or both are used because they provide excellent precursor solubility, as we reported previously for the synthesis of perovskite nanowires [22]. Introduction of a large ionic ligand, such as an ammonium or carboxylate-containing surfactant, decreases the perovskite particle size. In this study, the concentration of the $\mathrm{CH}_{3} \mathrm{NH}_{3} \mathrm{X}$ and larger alkyl ammonium halide, $\mathrm{n}-\mathrm{CH}_{3}\left(\mathrm{CH}_{2}\right)_{7} \mathrm{NH}_{3} \mathrm{X}$, are equivalent. In this way low-dimensional nanocrystalline perovskites are synthesized $[16,38,53]$. Perovskite nanocrystals produced by this method contain methyl ammonium cations within their core, and octyl ammonium groups on their surface [54].

$$
\mathrm{PbX}_{2}+3 \mathrm{CH}_{3} \mathrm{NH}_{3} \mathrm{X}+3 \mathrm{C}_{8} \mathrm{H}_{17} \mathrm{NH}_{3} \mathrm{X} \underset{\text { (2) Toluene }}{\text { (1) } \mathrm{CH}_{3} \mathrm{CN} \text { and/or DMF }}\left(\mathrm{CH}_{3} \mathrm{NH}_{3}\right)_{1-z}\left(\mathrm{C}_{8} \mathrm{H}_{17} \mathrm{NH}_{3}\right)_{z} \mathrm{PbX}_{3}
$$

Scheme 1. Synthesis of nanocrystalline organolead halide $(\mathrm{X}=\mathrm{Br}$ or I) perovskites prepared using a molar concentration of alkylammonium halide precursor that is $3 \times$ higher than that of the lead halide precursor; $0<\mathrm{z}$ $<<1$.

During the synthesis of iodide perovskites, the $\mathrm{PbI}_{2}$ precursor fails to dissolve completely in the cosolvent unless an excess of ammonium halide precursors is present. A very large excess of ammonium halides, however, irreversibly affects the optical properties of the resulting perovskites, as discussed below. Precursor reactivities and ease of forming solid solutions also affect the product. $\mathrm{CH}_{3} \mathrm{NH}_{3} \mathrm{X}$ salts dissociate differently in DMF depending on the specific halide (Scheme 2). For iodide, the preferred products are $\mathrm{CH}_{3} \mathrm{NH}_{3}{ }^{+}$and $\mathrm{I}^{-}$, the conjugate base of HI, which is a strong acid in DMF and leads to a large conductivity (Scheme 2, Fig. 1 when $\left[\mathrm{PbX}_{2}\right]_{0}=0$ ). For bromide the preferred products are $\mathrm{CH}_{3} \mathrm{NH}_{2}$ along with $\mathrm{HBr}$, which is a weaker acid in DMF and leads to a smaller conductivity (Scheme 2, Fig. 1 when $\left[\mathrm{PbX}_{2}\right]_{0}=0$ ). Thus, $\mathrm{CH}_{3} \mathrm{NH}_{3} \mathrm{I}$ is expected to be the most reactive ammonium halide precursor in DMF, generating free and readily available $\mathrm{I}^{-}$needed for perovskite formation that should be easily precipitated upon addition of a nonpolar solvent such as toluene.

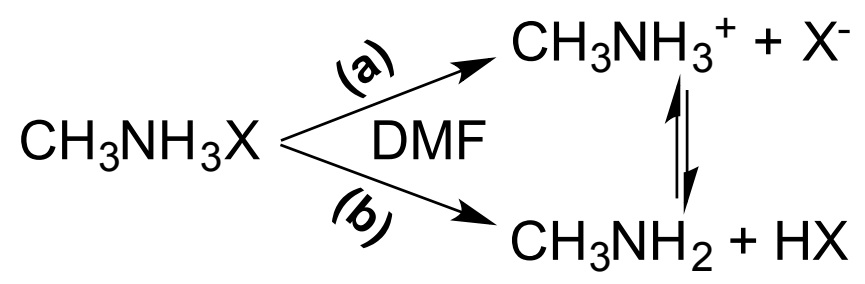

Scheme 2. Pathways of $\mathrm{CH}_{3} \mathrm{NH}_{3} \mathrm{X}$ dissociation in DMF. 
To probe $\mathrm{PbX}_{2}$ precursor reactivity, we measured their specific conductivities ( $\left.\kappa\right)$ in DMF with both the presence and absence of a set amount of the corresponding $\mathrm{CH}_{3} \mathrm{NH}_{3} \mathrm{X}$ (Fig. 1). As expected, in pure DMF, the conductivity increases linearly with $\mathrm{PbX}_{2}$ concentration. Conductivity is proportional to the number of ions in solution, thus enabling a comparison to the relative degree of dissociation and association. A steeper increase for the iodide case suggests that dissociation is slightly higher for $\mathrm{PbI}_{2}$ than for $\mathrm{PbBr}_{2}$. With the presence of 50 $\mathrm{mM} \mathrm{CH} \mathrm{NH}_{3} \mathrm{X}$ in DMF, the conductivity actually decreases upon addition of $\mathrm{PbI}_{2}$ and slowly increases upon addition of $\mathrm{PbBr}_{2}$. When a 1 to 3 ratio of $\mathrm{PbX}_{2}$ to $\mathrm{CH}_{3} \mathrm{NH}_{3} \mathrm{X}$ is used, as is the case in the Scheme 1 perovskites, the conductivity is higher for $\mathrm{PbI}_{2} / \mathrm{CH}_{3} \mathrm{NH}_{3} \mathrm{I}$ than $\mathrm{PbBr}_{2} / \mathrm{CH}_{3} \mathrm{NH}_{3} \mathrm{Br}$ suggesting that $\mathrm{Pb}-\mathrm{Br}$ binding in solution is stronger than $\mathrm{Pb}-\mathrm{I}$ binding. A similar observation was reported by luminescence and transient absorption measurements [55].

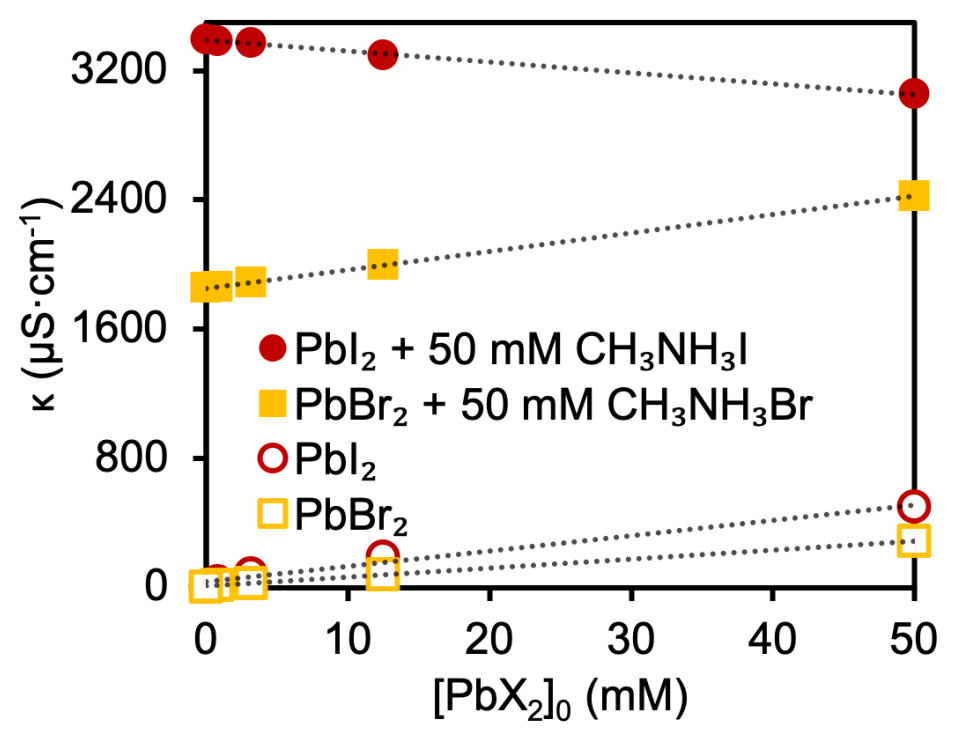

Fig. 1. Specific conductivity ( $\kappa$ ) vs. $\mathrm{PbX}_{2}$ concentration with (solid) or without (hollow) $50 \mathrm{mM} \mathrm{CH}_{3} \mathrm{NH}_{3} \mathrm{X}$.

\section{Structural Analysis}

Powder X-ray diffraction (XRD) patterns show the diffraction peaks corresponding to the $<110>$ and $<001>$ facets of the $\mathrm{CH}_{3} \mathrm{NH}_{3} \mathrm{PbI}_{3}$ and $\mathrm{CH}_{3} \mathrm{NH}_{3} \mathrm{PbBr}_{3}$ nanocrystals (Fig. 2). $\mathrm{CH}_{3} \mathrm{NH}_{3} \mathrm{PbBr}_{3}$ shifts to higher $2 \theta$ values since bromine has a higher electronegativity compared to iodine, indicating some degree of solid solution, consistent with literature [56, 57]. Table 1 presents the lattice parameter of cubic $\mathrm{CH}_{3} \mathrm{NH}_{3} \mathrm{PbBr}_{3}$ and tetragonal $\mathrm{CH}_{3} \mathrm{NH}_{3} \mathrm{PbI}_{3}$ nanocrystalline perovskites as determined experimentally from $\mathrm{XRD}$ analysis. 


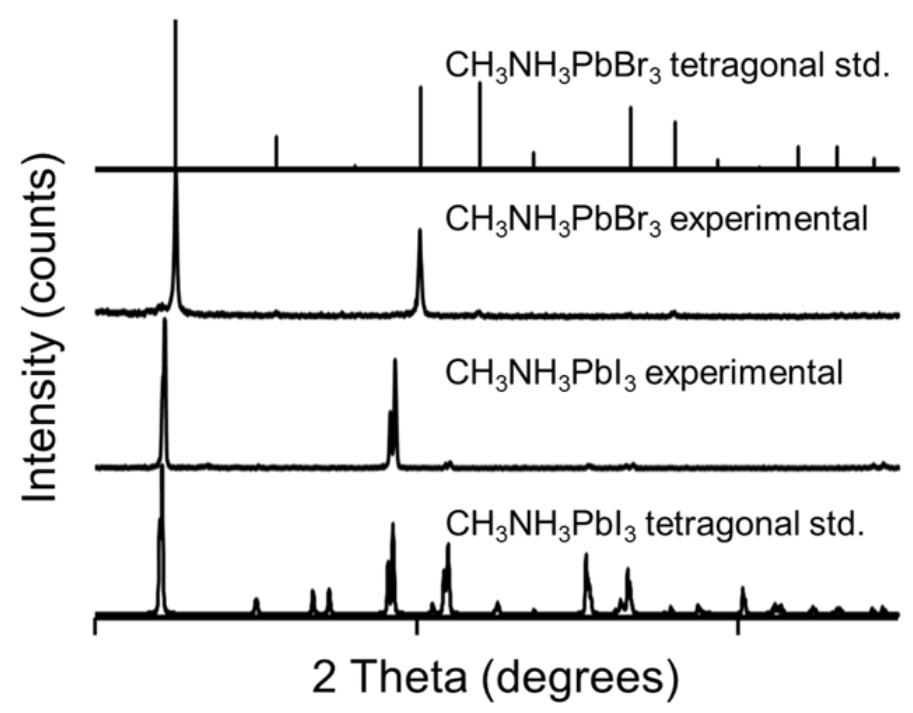

Fig. 2. Powder XRD of nanocrystalline organometal halide perovskites with corresponding standard (std.) diffraction patterns.

The transmission electron microscopy (TEM) images shown in Fig. 3 reveal that the perovskites are primarily nanospheres with an average size of $7 \pm 2 \mathrm{~nm}$ for $\mathrm{CH}_{3} \mathrm{NH}_{3} \mathrm{PbI}_{3}$ and $8 \pm 2 \mathrm{~nm}$ for $\mathrm{CH}_{3} \mathrm{NH}_{3} \mathrm{PbBr}_{3}$. The Bohr radii for bromide and iodide perovskites are 2 and $2.2 \mathrm{~nm}$, respectively [58]. In addition to the nanospheres, the $\mathrm{CH}_{3} \mathrm{NH}_{3} \mathrm{PbBr}_{3}$ perovskites exhibit nanosheets making up $c a$. $10-20 \%$ of the total particles. As we previously reported, perovskite nanosheets are unstable under the TEM electron beam [22]. The presence of nanosheets is a contributing factor for the preferred orientation behavior observed by powder XRD for $\mathrm{CH}_{3} \mathrm{NH}_{3} \mathrm{PbI}_{3}$ perovskite nanocrystals.
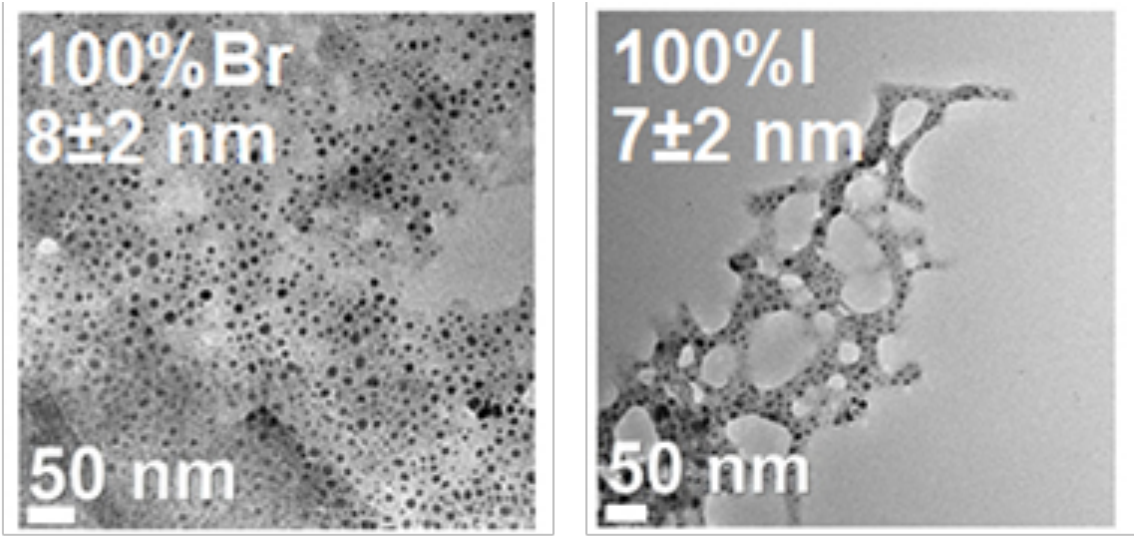

Fig. 3. Representative TEM images of $\mathrm{CH}_{3} \mathrm{NH}_{3} \mathrm{PbBr}_{3}$ and $\mathrm{CH}_{3} \mathrm{NH}_{3} \mathrm{PbI}_{3}$ nanocrystalline perovskites.

\section{Optical Properties and Photostability}

Using a spectrofluorometer with arc lamp illumination, the $\lambda_{\max }$ for $\mathrm{CH}_{3} \mathrm{NH}_{3} \mathrm{PbI}_{3}$ was determined to be $760 \mathrm{~nm}$; and that for $\mathrm{CH}_{3} \mathrm{NH}_{3} \mathrm{PbBr}_{3}, 518 \mathrm{~nm}$. This is consistent with literature reports for perovskites of similar composition [59-61]. The $\mathrm{CH}_{3} \mathrm{NH}_{3} \mathrm{PbBr}_{3}$ perovskite sample has a 29-fold higher photoluminescence quantum yield (44\%) compared to $\mathrm{CH}_{3} \mathrm{NH}_{3} \mathrm{PbI}_{3}$ (Table 1). 
Table 1. Characterization parameters of low-dimensional organometal halide perovskites.

\begin{tabular}{|c|c|c|c|c|c|c|c|}
\hline Loading & $\begin{array}{c}\mathbf{a}^{\mathbf{1}} \\
(\mathbf{n m})\end{array}$ & $\begin{array}{c}\text { Scherrer } \\
\text { Size (nm) }\end{array}$ & $\begin{array}{c}\text { TEM } \\
\text { Size (nm) }\end{array}$ & $\begin{array}{c}\text { Abs. } \\
\text { Edge } \\
\mathbf{( n m )}\end{array}$ & $\begin{array}{c}\text { Band } \\
\text { Gap (eV) }\end{array}$ & $\begin{array}{c}\text { First-Exciton } \\
\text { Luminescence } \\
(\mathbf{n m})\end{array}$ & $\begin{array}{c}\text { Quantum } \\
\text { Yield } \\
\mathbf{( \% )}\end{array}$ \\
\hline $\mathrm{CH}_{3} \mathrm{NH}_{3} \mathrm{PbBr}_{3}$ & 0.587 & 7 & $8 \pm 2$ & 527 & 2.35 & 506 & 44 \\
\hline $\mathrm{CH}_{3} \mathrm{NH}_{3} \mathrm{PbI}_{3}$ & 0.634 & $>100$ & $7 \pm 2$ & 774 & 1.60 & 745 & 1.5 \\
\hline
\end{tabular}

${ }^{1}$ Lattice parameter (a). ${ }^{2}$ More than 100 nanocrystals measured.

Nanocrystalline perovskites prepared using Scheme 1 with an a:b:c precursor ratio of 1:3:3 exhibited two luminescence peaks in a flash photolysis experiment with nanosecond pulsed Nd:YAG laser illumination. One peak had a $\lambda_{\max }$ at $745 \mathrm{~nm}(\mathrm{Eg})$ and the second peak had a $\lambda_{\max }$ at $642 \mathrm{~nm}(\mathrm{E}>\mathrm{Eg})$ for $\mathrm{CH}_{3} \mathrm{NH}_{3} \mathrm{PbI}_{3}$ and 0.01 $\mathrm{mJ}$ pulsed-laser illumination (Fig. 4a). With increasing excitation energy the relative intensity of the $642 \mathrm{~nm}$ peak increases nonlinearly (Fig. 4b) and both peaks blue shift. With $12 \mathrm{~mJ}$ illumination, the $\lambda_{\max }$ are $626 \mathrm{~nm}$ and $725 \mathrm{~nm}$.
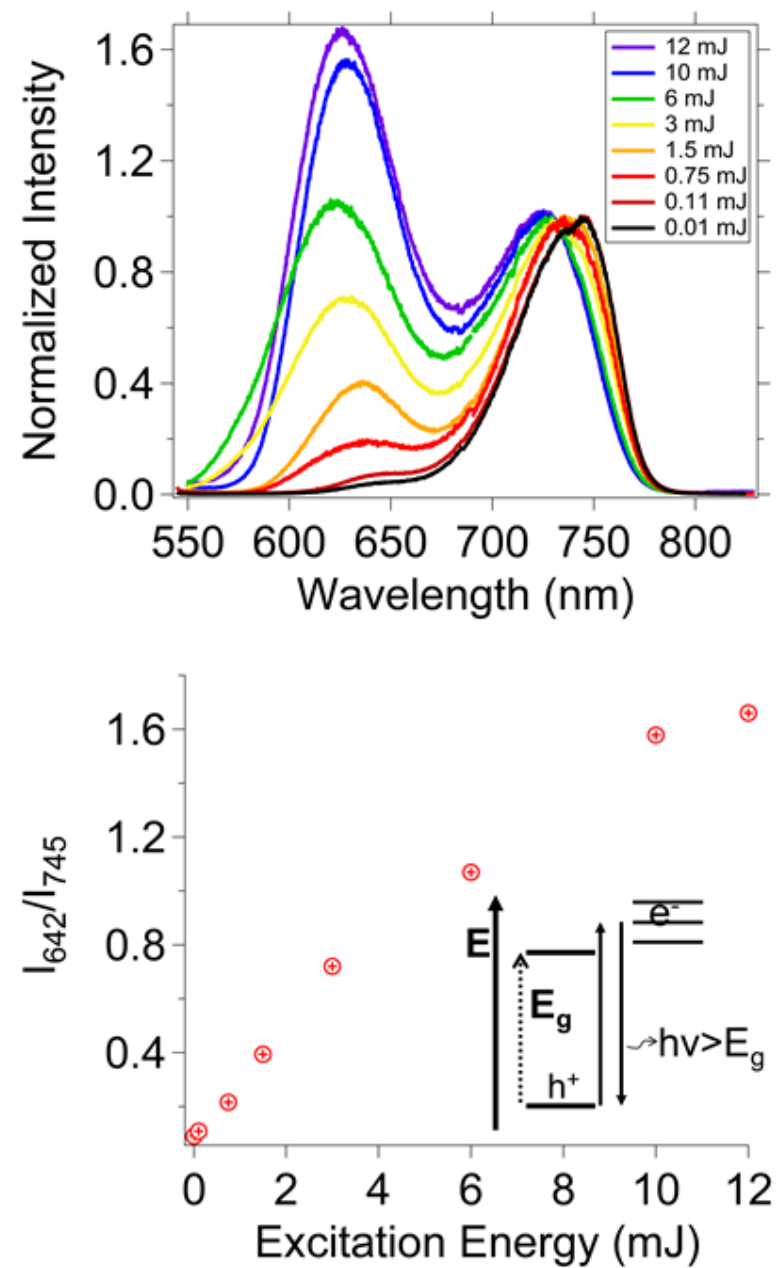

Fig. 4. (Top) Flash photolysis luminescence spectra of nanocrystalline $\mathrm{CH}_{3} \mathrm{NH}_{3} \mathrm{PbI}_{3}$, prepared using Scheme 1 , as a function of excitation power. The spectra are normalized to the intensity at $\sim 745 \mathrm{~nm}$ (at the $\lambda_{\max }$ ). (Bottom) Intensity ratios of the $\sim 642 \mathrm{~nm}$ ( $\left.\mathrm{I}_{642}\right)$ and $\sim 745 \mathrm{~nm}$ (I $\left.{ }_{745}\right)$ bands vs. incident laser power. The inset explains the band gap $\left(\mathrm{E}_{\mathrm{g}}\right)$ of the nanocrystalline perovskite "vs" the higher energy trap state luminescence. 
To determine if the photoinitiated increase in the $642 \mathrm{~nm}$ peak intensity was reversible, the luminescence spectrum of the $\mathrm{CH}_{3} \mathrm{NH}_{3} \mathrm{PbI}_{3}$ nanocrystals was monitored in a new-batch of nanocrystals after blocking the laser irradiation. After 300 minutes in the dark, the intensity of the band at $642 \mathrm{~nm}$ decreased due to a thermal relaxation mechanism. The photoinitiated reversible spectral changes may be the result of changes in the crystal phase or the population of surface traps.

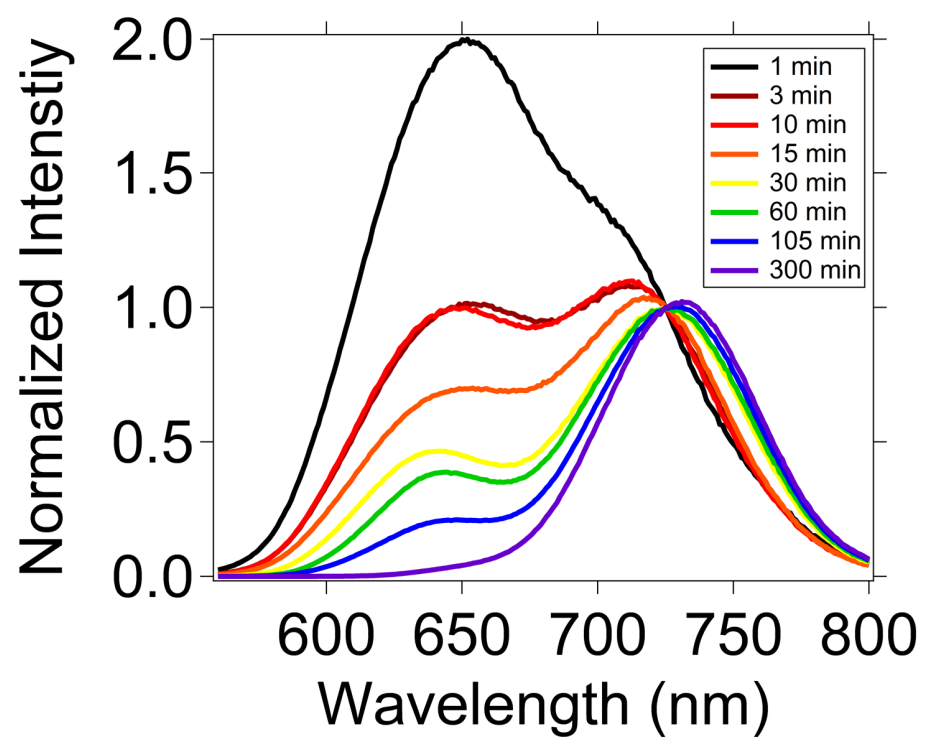

Fig. 5. Flash photolysis luminescence spectra of nanocrystalline $\mathrm{CH}_{3} \mathrm{NH}_{3} \mathrm{PbI}_{3}$ made with Scheme 1 showing thermal relaxation subsequent to laser illumination from a $532-\mathrm{nm}, 15-\mathrm{mJ} \mathrm{Nd}: Y A G$ laser providing nanosecond pulses. Time zero corresponds to the time when the laser was blocked from illuminating the sample.

In order to rule out phase changes as the cause of the photoinduced spectral changes, we conducted in situ XRD experiments to search for possible structural changes in the nanocrystalline perovskites during illumination with a pulsed laser. An open window was used to irradiate the samples while they were mounted in the XRD instrument as we have previously reported for other in situ XRD measurements [51]. The nanocrystalline material was in the solid state so no solvent effects were present. The $\mathrm{CH}_{3} \mathrm{NH}_{3} \mathrm{PbI}_{3}$ nanocrystalline perovskites exhibited no change in $2 \theta$ diffraction peak location or new peaks as a result of irradiation with a laser energy up to $15 \mathrm{~mJ}$ (Fig. 6). The in situ XRD analysis revealed no additional or shifted diffraction peaks, which indicates that a phase transition does not occur upon illumination. 


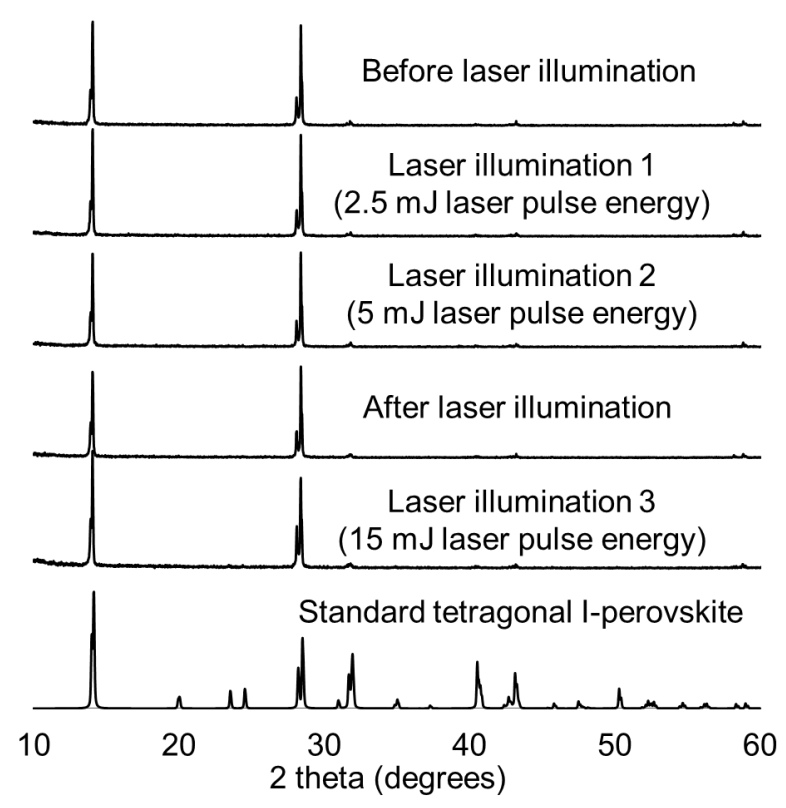

Fig. 6. X-ray diffraction patterns from nanocrystalline $\mathrm{CH}_{3} \mathrm{NH}_{3} \mathrm{PbI}_{3}$ perovskites at different pulse energies. The laser illuminated the sample during the entire time XRD data were collected.

Since a phase change was not measured upon irradiating the sample, the photoinitiated blue photoluminescence peak may result from surface trap states that are populated upon irradiation. In this case, the perovskites have traps with energies above the conduction band that emit at higher energies than the band gap (Fig. 4b inset). An increasing population in trap states with increasing irradiation power could explain the increasing intensity of the $630-\mathrm{nm}$ peak in going from $0.01 \mathrm{~mJ}$ to $12 \mathrm{~mJ}$ (Fig. 4). Excess precursor may lead to higher energy emissive states which differ from the traditional nanocrystalline lattice expected for $\mathrm{CH}_{3} \mathrm{NH}_{3} \mathrm{PbI}_{3}$ nanocrystals. By using a precursor ratio of 1:1.5:1.5 (Scheme 2), the $\mathrm{CH}_{3} \mathrm{NH}_{3} \mathrm{PbBr}_{3}$ and $\mathrm{CH}_{3} \mathrm{NH}_{3} \mathrm{PbI}_{3}$ exhibited only one luminescence peak at $540 \mathrm{~nm}$ and $800 \mathrm{~nm}$, respectively (Fig. 7a, 8a). The disappearance of a second luminescence peak illustrates that bromide and iodide nanocrystalline perovskites prepared using Scheme 2 each have a single emitting state compared to the multiple emitting states observed for the nanocrystals prepared using Scheme 1 with a higher precursor ratio. This observation supports the hypothesis that a synthesis using the smaller ratio of precursors may result in nanocrystals with higher crystalline order and fewer defects compared to a synthesis using a larger precursor ratio.

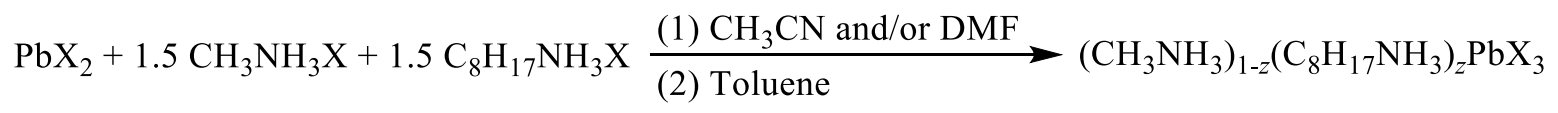

Scheme 2. Optimized synthesis of nanocrystalline organolead halide ( $\mathrm{X}=\mathrm{I}$ or $\mathrm{Br}$ ) perovskites prepared using a molar concentration of alkylammonium halide precursor that is $1.5 \times$ that of the lead halide precursor; $0<\mathrm{z}$ $<<1$. 

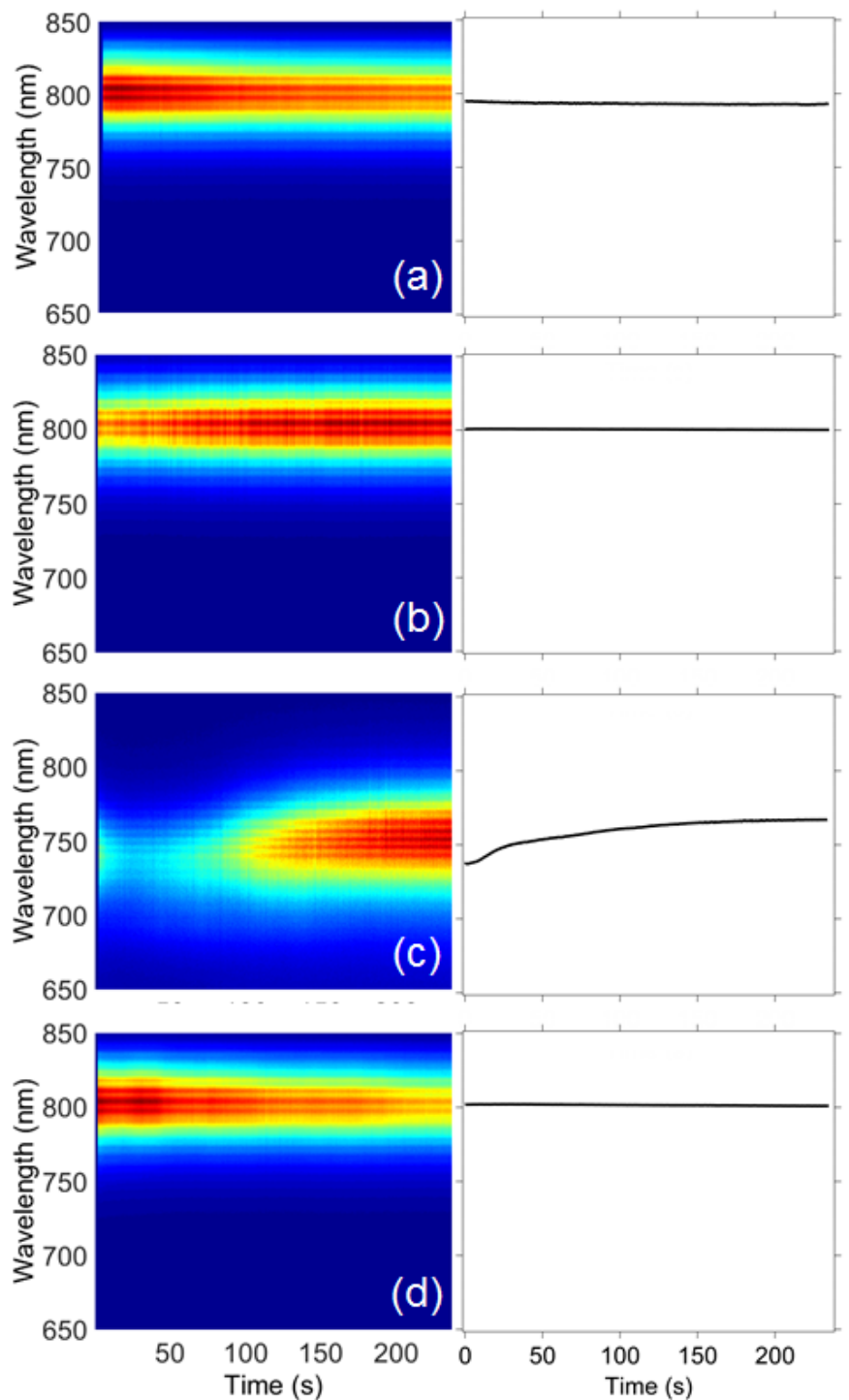

Fig. 7 Time-correlated luminescence microspectroscopy spectra of single $\mathrm{CH}_{3} \mathrm{NH}_{3} \mathrm{PbI}_{3}$ perovskites. The left column shows the plots of luminescence versus illumination time with a $532 \mathrm{~nm}$ laser $\left(1.58 \times 10^{5} \mathrm{~W} / \mathrm{cm}^{2}\right)$ for $\mathrm{CH}_{3} \mathrm{NH}_{3} \mathrm{PbI}_{3}$ perovskites synthesized using Scheme 2. The samples are: (a) unwashed sample, (b) washed sample, (c) unwashed with excess precursor, and (d) washed with excess precursor sample. The right column shows the average $\lambda_{\max }$ versus illumination time $(\mathrm{n}=3)$. 

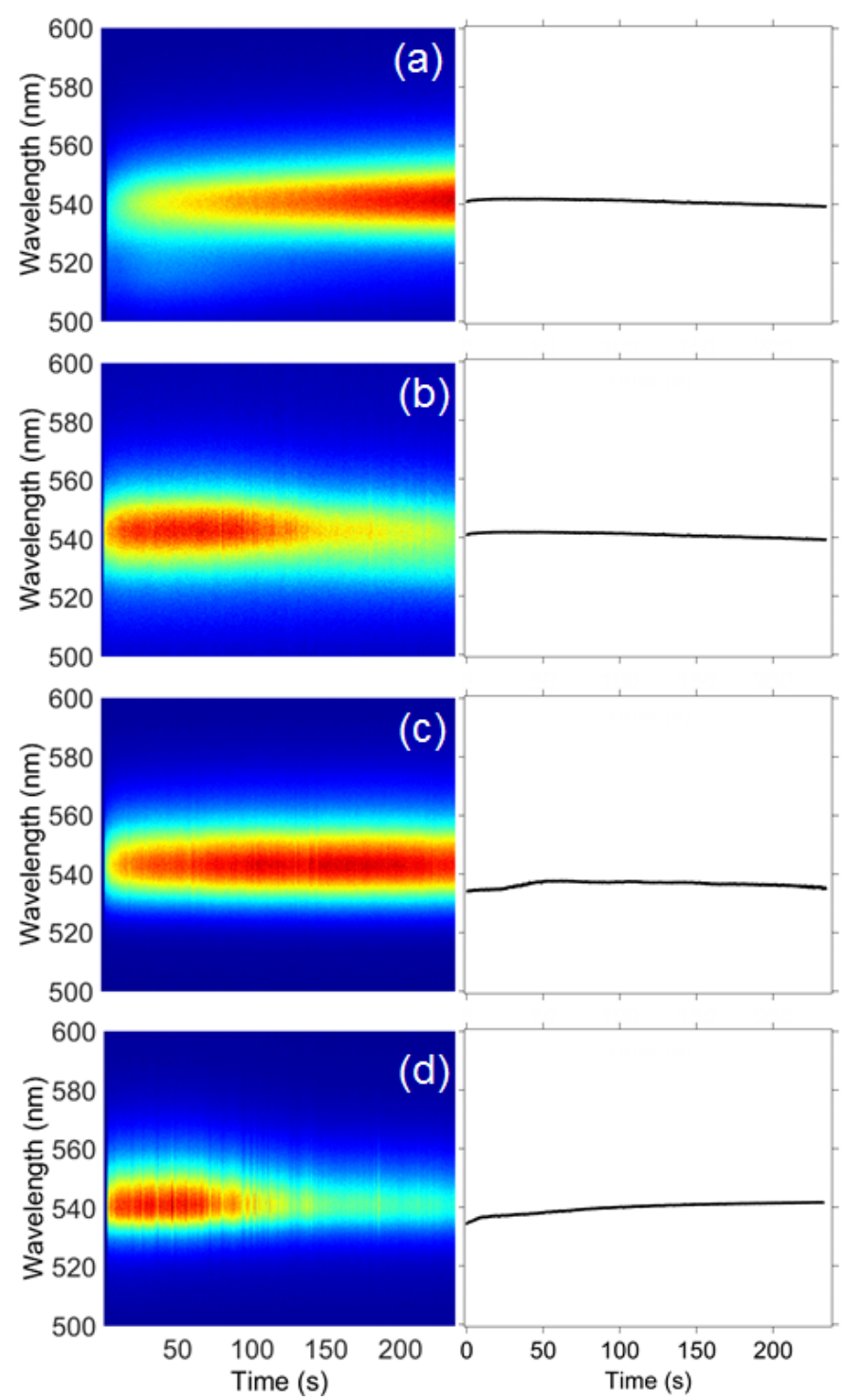

Fig. 8 Time-correlated luminescence microspectroscopy spectra of single $\mathrm{CH}_{3} \mathrm{NH}_{3} \mathrm{PbBr}_{3}$ perovskites. The left column shows the plots of luminescence versus illumination time with a $488 \mathrm{~nm}$ laser $\left(1.58 \times 10^{5} \mathrm{~W} / \mathrm{cm}^{2}\right)$ for $\mathrm{CH}_{3} \mathrm{NH}_{3} \mathrm{PbBr}_{3}$ perovskites synthesized using Scheme 2. The samples are: (a) unwashed sample, (b) washed sample, (c) unwashed with excess precursor, and (d) washed with excess precursor sample. The right column shows the average $\lambda_{\max }$ versus illumination time $(\mathrm{n}=3)$.

Any deviations in $\lambda_{\max }$ are less than $4 \mathrm{~nm}$, and can be explained as measurement uncertainty (e.g., minor changes to the focus). Hu et al. measured no shifts in the luminescence $\lambda_{\max }$ for a single $\mathrm{CsPbI}_{3}$ nanocrystal after $600 \mathrm{~s}$ when excited using a pulsed laser at a temperature of $4 \mathrm{~K}$ [62]. They reported a resolution-limited peak width of about $200 \mu \mathrm{eV}$, but a laser power density was not reported that could be compared to the experimental parameters we used. Rainò et al. also observed a stable luminescence $\lambda_{\max }$ for a mixed halide $\mathrm{CsPb}(\mathrm{Br} / \mathrm{Cl})_{3}$ nanocrystal measured for $60 \mathrm{~s}$ at $6 \mathrm{~K}$ using $92 \mathrm{~W} / \mathrm{cm}^{2}$ excitation [63]. Multiple luminescence peaks and a shifting $\lambda_{\max }$ were measured at higher power densities (up to $4.7 \times 10^{3} \mathrm{~W} / \mathrm{cm}^{2}$ ); the 
time-correlated luminescence behavior varied from one nanocrystal to another. In our study, nine of the $\mathrm{CH}_{3} \mathrm{NH}_{3} \mathrm{PbI}_{3}$ nanocrystals measured at room temperature exhibited stable time-correlated luminescence at a higher excitation power density than used by Rainò et al., while three showed a $<79$-nm shift in $\lambda_{\max }$. Eight of the $\mathrm{CH}_{3} \mathrm{NH}_{3} \mathrm{PbBr}_{3}$ nanocrystals we measured exhibited stable luminescence behavior while four showed a $<8$ $\mathrm{nm}$ shift in $\lambda_{\max }$.

To examine the stability of perovskites prepared using the optimized synthetic method with prolonged illumination, luminescence microspectroscopy of individual nanocrystals was employed. For this experiment, a batch of 24-hour-aged perovskites in toluene was divided into four samples. One sample was left as is, and is referred to as the "unwashed sample." The second sample was mixed with additional 0.012-mM alkylammonium halide (i.e., the same concentration as the precursor solution) and was labeled "unwashed with excess precursor." For the third and fourth samples, the perovskites were precipitated from the product solution and were resuspended in toluene ("washed sample") or an 0.01- $\mathrm{mM}$ alkylammonium halide solution in toluene ("washed with excess precursor sample").

The $\mathrm{CH}_{3} \mathrm{NH}_{3} \mathrm{PbI}_{3}$ perovskites prepared using Scheme 2 exhibited a constant $\lambda_{\max }$ of $800 \mathrm{~nm}$ for all samples except the unwashed sample with excess precursor. For the latter, the $\lambda_{\max }$ shifts from $737 \mathrm{~nm}$ at the start of illumination to $767 \mathrm{~nm}$ after $240 \mathrm{~s}$ of illumination. Thus, for $\mathrm{CH}_{3} \mathrm{NH}_{3} \mathrm{PbI}_{3}$ additional precursor affects the photostability whether it is present during the synthesis or added post synthesis, although the effect varies (e.g., blue-shifted peak versus red-shifted peak). While the $\lambda_{\max }$ is stable for most of the $\mathrm{CH}_{3} \mathrm{NH}_{3} \mathrm{PbI}_{3}$ samples, the luminescence intensity is variable over the measurement period and photobrightening or photobleaching was measured for most of the nanocrystals (Fig. S2). We have previously reported and discussed this behavior [61].

The nanocrystalline $\mathrm{CH}_{3} \mathrm{NH}_{3} \mathrm{PbBr}_{3}$ perovskites prepared using the optimized synthesis (Scheme 2) exhibited a constant luminescence $\lambda_{\max }$ around $540 \mathrm{~nm}$ (Fig. 8) for all samples, even when additional precursor was added to the washed nanocrystals. (No shifts of $\lambda_{\max }$ greater than 4 nanometers were measured). Freppon et al. report the emission of these nanocrystals to be $498 \mathrm{~nm}$ when measured in toluene [61]. The red shift in $\lambda_{\max }$ measured for the time-correlated luminescence spectra were measured in the dry state, which explains the difference in the $\lambda_{\max }$ for these two studies. The fact that the luminescence $\lambda_{\max }$ does not shift after adding excess precursor to the nanocrystals synthesized with the optimized method indicates that the higher precursor concentration must be present during the synthesis to have an effect on generating the photoinitiated luminescence peaks for $\mathrm{CH}_{3} \mathrm{NH}_{3} \mathrm{PbBr}_{3}$. Photobrightening and photobleaching were also recorded for $\mathrm{CH}_{3} \mathrm{NH}_{3} \mathrm{PbBr}_{3}$ nanocrystals (Fig. S3).

\section{Conclusion}

In order to be useful in a variety of applications, nanocrystalline perovskites need to be photostable. The non-optimized organometal halide perovskites show shifts in luminescence $\lambda_{\max }$ and exhibit multiple luminescence peaks when excess alkylammonium precursor is used. The optimized synthetic method produces nanocrystalline methylammonium lead halide particles that are photostable over at least 4 minutes of focused illumination. The mechanism for the improved photostability is likely to be reduced surface traps when low precursor ratios are utilized. This work reports on the photostability of perovskites containing a single halide. Similar synthetic methods may increase the photostability of related perovskites. In the case of mixed-halide perovskite nanocrystals, where domains of heterogeneous halide compositions may exist, the photostability is more complicated. For example, our initial investigation has shown that $\mathrm{CH}_{3} \mathrm{NH}_{3} \mathrm{~Pb}(\mathrm{Br} 0.2 \mathrm{I} 0.8)_{3}$ nanocrystalline perovskites exhibit an abrupt shift in $\lambda_{\max }$ from $630 \mathrm{~nm}$ to $750 \mathrm{~nm}$ after a few seconds of illumination followed by a constant $\lambda_{\max }$ with additional illumination (Fig. S4). Under indentical conditions, our initial investigations indicate that single-halide perovskites exhibit stable $\lambda_{\max }$ as reported in this work. Thus, the continued study of mixed-halide perovskites should be pursued. 


\section{Acknowledgment}

This research is supported by the U.S. Department of Energy, Office of Basic Energy Sciences, Division of Chemical Sciences, Geosciences, and Biosciences through the Ames Laboratory. The Ames Laboratory is operated for the U.S. Department of Energy by Iowa State University under Contract No. DEAC02-07CH11358. We thank Miles Arthur White for assistance with graphics.

\section{References}

1. Green, M. A.; Ho-Baillie, A. ACS Energy Letters. 2017, 2, 822-830

2. Li, Z.; Klein, T. R.; Kim, D. H.; Yang, M.; Berry, J. J.; van Hest, M. F.; Zhu, K. Nature Reviews Materials. 2018, 3, 18017

3. Sutherland, B. R.; Sargent, E. H. Nature Photonics. 2016, 10, 295

4. Dong, Q.; Fang, Y.; Shao, Y.; Mulligan, P.; Qiu, J.; Cao, L.; Huang, J. Science. 2015, 347, 967-970

5. Kojima, A.; Teshima, K.; Shirai, Y.; Miyasaka, T. Journal of the American Chemical Society. 2009, 131, 6050-6051

6. Liu, M.; Johnston, M. B.; Snaith, H. J. Nature. 2013, 501, 395

7. Burschka, J.; Pellet, N.; Moon, S.-J.; Humphry-Baker, R.; Gao, P.; Nazeeruddin, M. K.; Grätzel, M. Nature. 2013, 499, 316-319

8. Zhou, H.; Chen, Q.; Li, G.; Luo, S.; Song, T.-b.; Duan, H.-S.; Hong, Z.; You, J.; Liu, Y.; Yang, Y. Science. 2014, 345, 542-546

9. Yang, W. S.; Noh, J. H.; Jeon, N. J.; Kim, Y. C.; Ryu, S.; Seo, J.; Seok, S. I. Science. 2015, 348, $1234-$ 1237

10. Yang, W. S.; Park, B.-W.; Jung, E. H.; Jeon, N. J.; Kim, Y. C.; Lee, D. U.; Shin, S. S.; Seo, J.; Kim, E. K.; Noh, J. H. Science. 2017, 356, 1376-1379

11. Christians, J. A.; Miranda Herrera, P. A.; Kamat, P. V. Journal of the American Chemical Society. 2015, 137, 1530-1538

12. Bert, C.; Jeroen, D.; Nicolas, G.; Aslihan, B.; Jan, D. H.; Lien, D. O.; Anitha, E.; Jo, V.; Jean, M.; Edoardo, M.; De, A. F.; Hans-Gerd, B. Advanced Energy Materials. 2015, 5, 1500477

13. Berhe, T. A.; Su, W.-N.; Chen, C.-H.; Pan, C.-J.; Cheng, J.-H.; Chen, H.-M.; Tsai, M.-C.; Chen, L.Y.; Dubale, A. A.; Hwang, B.-J. Energy \& Environmental Science. 2016, 9, 323-356

14. Samrana, K.; Khaja, N. M.; Michael, G.; Shahzada, A. Angewandte Chemie International Edition. 2014, 53, 2812-2824

15. Gao, P.; Grätzel, M.; Nazeeruddin, M. K. Energy \& Environmental Science. 2014, 7, 2448-2463

16. Dou, L.; Wong, A. B.; Yu, Y.; Lai, M.; Kornienko, N.; Eaton, S. W.; Fu, A.; Bischak, C. G.; Ma, J.; Ding, T. Science. 2015, 349, 1518-1521

17. Boix, P. P.; Agarwala, S.; Koh, T. M.; Mathews, N.; Mhaisalkar, S. G. The Journal of Physical Chemistry Letters. 2015, 6, 898-907

18. Sichert, J. A.; Tong, Y.; Mutz, N.; Vollmer, M.; Fischer, S.; Milowska, K. Z.; García Cortadella, R.; Nickel, B.; Cardenas-Daw, C.; Stolarczyk, J. K. Nano Letters. 2015, 15, 6521-6527

19. Protesescu, L.; Yakunin, S.; Bodnarchuk, M. I.; Krieg, F.; Caputo, R.; Hendon, C. H.; Yang, R. X.; Walsh, A.; Kovalenko, M. V. Nano Letters. 2015, 15, 3692-3696

20. Deschler, F.; Price, M.; Pathak, S.; Klintberg, L. E.; Jarausch, D.-D.; Higler, R.; Hüttner, S.; Leijtens, T.; Stranks, S. D.; Snaith, H. J.; Atatüre, M.; Phillips, R. T.; Friend, R. H. The Journal of Physical Chemistry Letters. 2014, 5, 1421-1426

21. Zhang, F.; Zhong, H.; Chen, C.; Wu, X.-g.; Hu, X.; Huang, H.; Han, J.; Zou, B.; Dong, Y. ACS Nano. 2015, 9, 4533-4542

22. Zhu, F.; Men, L.; Guo, Y.; Zhu, Q.; Bhattacharjee, U.; Goodwin, P. M.; Petrich, J. W.; Smith, E. A.; Vela, J. ACS Nano. 2015, 9, 2948-2959

23. Yang, Z.; Zhang, W.-H. Chinese Journal of Catalysis. 2014, 35, 983-988 
24. Stranks, S. D.; Nayak, P. K.; Zhang, W.; Stergiopoulos, T.; Snaith, H. J. Angewandte Chemie International Edition. 2015, 54, 3240-3248

25. Yan, K.; Long, M.; Zhang, T.; Wei, Z.; Chen, H.; Yang, S.; Xu, J. Journal of the American Chemical Society. 2015, 137 (13), 4460-4468

26. Tan, Z.-K.; Moghaddam, R. S.; Lai, M. L.; Docampo, P.; Higler, R.; Deschler, F.; Price, M.; Sadhanala, A.; Pazos, L. M.; Credgington, D.; Hanusch, F.; Bein, T.; Snaith, H. J.; Friend, R. H. Nature Nanotechnology. 2014, 9, 687-692

27. Zhang, M.; Yu, H.; Lyu, M.; Wang, Q.; Yun, J.-H.; Wang, L. Chemical Communications. 2014, 50, 11727-11730

28. Jang, D. M.; Park, K.; Kim, D. H.; Park, J.; Shojaei, F.; Kang, H. S.; Ahn, J.-P.; Lee, J. W.; Song, J. K. Nano Letters. 2015, 15, 5191-5199

29. Noh, J. H.; Im, S. H.; Heo, J. H.; Mandal, T. N.; Seok, S. I. Nano Letters. 2013, 13, 1764-1769

30. Dimesso, L.; Dimamay, M.; Hamburger, M.; Jaegermann, W. Chemistry of Materials. 2014, 26, 67626770

31. Misra, R. K.; Aharon, S.; Li, B.; Mogilyansky, D.; Visoly-Fisher, I.; Etgar, L.; Katz, E. A. The Journal of Physical Chemistry Letters. 2014, 326-330

32. Hoke, E. T.; Slotcavage, D. J.; Dohner, E. R.; Bowring, A. R.; Karunadasa, H. I.; McGehee, M. D. Chemical Science. 2015, 6, 613-617

33. Sadhanala, A.; Deschler, F.; Thomas, T. H.; Dutton, S. E.; Goedel, K. C.; Hanusch, F. C.; Lai, M. L.; Steiner, U.; Bein, T.; Docampo, P.; Cahen, D.; Friend, R. H. The Journal of Physical Chemistry Letters. 2014, 5, 2501-2505

34. Gottesman, R.; Gouda, L.; Kalanoor, B. S.; Haltzi, E.; Tirosh, S.; Rosh-Hodesh, E.; Tischler, Y.; Zaban, A.; Quarti, C.; Mosconi, E. The Journal of Physical Chemistry Letters. 2015, 6, 2332-2338

35. Shao, Y.; Xiao, Z.; Bi, C.; Yuan, Y.; Huang, J. Nature Communications. 2014, 5, 5784

36. Yuan, Y.; Huang, J. Accounts of Chemical Research. 2016, 49, 286-293

37. Stranks, S. D.; Burlakov, V. M.; Leijtens, T.; Ball, J. M.; Goriely, A.; Snaith, H. J. Physical Review Applied. 2014, 2, 034007

38. Wu, X.; Trinh, M. T.; Niesner, D.; Zhu, H.; Norman, Z.; Owen, J. S.; Yaffe, O.; Kudisch, B. J.; Zhu, X.-Y. Journal of the American Chemical Society. 2015, 137, 2089-2096

39. Wehrenfennig, C.; Liu, M.; Snaith, H. J.; Johnston, M. B.; Herz, L. M. The Journal of Physical Chemistry Letters. 2014, 5, 1300-1306

40. Lee, M. M.; Teuscher, J.; Miyasaka, T.; Murakami, T. N.; Snaith, H. J. Science. 2012, 338, 643-647

41. Agiorgousis, M. L.; Sun, Y.-Y.; Zeng, H.; Zhang, S. Journal of the American Chemical Society. 2014, 136, 14570-14575

42. Sangni, W.; Furong, H.; Liya, Z.; Jianwu, W.; Youling, X.; Peng, J.; Zhuo, C.; Zuodong, Y.; Qi, P.; Zhong, Z. J. ChemNanoMat. 2018, 4, 409-416

43. Yin, W.-J.; Shi, T.; Yan, Y. Applied Physics Letters. 2014, 104, 063903

44. Wan-Jian, Y.; Tingting, S.; Yanfa, Y. Advanced Materials. 2014, 26, 4653-4658

45. Kim, J.; Lee, S.-H.; Lee, J. H.; Hong, K.-H. The Journal of Physical Chemistry Letters. 2014, 5, 13121317

46. Shi, T.; Yin, W.-J.; Hong, F.; Zhu, K.; Yan, Y. Applied Physics Letters. 2015, 106, 103902

47. Buin, A.; Pietsch, P.; Xu, J.; Voznyy, O.; Ip, A. H.; Comin, R.; Sargent, E. H. Nano Letters. 2014, 14, 6281-6286

48. Abate, A.; Saliba, M.; Hollman, D. J.; Stranks, S. D.; Wojciechowski, K.; Avolio, R.; Grancini, G.; Petrozza, A.; Snaith, H. J. Nano Letters. 2014, 14, 3247-3254

49. Noel, N. K.; Abate, A.; Stranks, S. D.; Parrott, E. S.; Burlakov, V. M.; Goriely, A.; Snaith, H. J. ACS Nano. 2014, 8, 9815-9821

50. Xu, J.; Buin, A.; Ip, A. H.; Li, W.; Voznyy, O.; Comin, R.; Yuan, M.; Jeon, S.; Ning, Z.; McDowell, J. J. Nature Communications. 2015, 6, 7081

51. Bhattacharjee, U.; Freppon, D.; Men, L.; Vela, J.; Smith, E. A.; Petrich, J. W. ChemPhysChem. 2017, 18 (18), 2526-2532

52. Grabolle, M.; Spieles, M.; Lesnyak, V.; Gaponik, N.; Eychmüller, A.; Resch-Genger, U. Analytical Chemistry. 2009, 81, 6285-6294 
53. Schmidt, L. C.; Pertegás, A.; González-Carrero, S.; Malinkiewicz, O.; Agouram, S.; Mínguez Espallargas, G.; Bolink, H. J.; Galian, R. E.; Pérez-Prieto, J. Journal of the American Chemical Society. 2014, 136, 850-853

54. De Roo, J.; Ibáñez, M.; Geiregat, P.; Nedelcu, G.; Walravens, W.; Maes, J.; Martins, J. C.; Van Driessche, I.; Kovalenko, M. V.; Hens, Z. ACS Nano. 2016, 10, 2071-2081

55. Yoon, S. J.; Stamplecoskie, K. G.; Kamat, P. V. The Journal of Physical Chemistry Letters. 2016, 7, 1368-1373

56. Rosales, B. A.; Hanrahan, M. P.; Boote, B. W.; Rossini, A. J.; Smith, E. A.; Vela, J. ACS Energy Letters. 2017, 2, 906-914

57. Fedeli, P.; Gazza, F.; Calestani, D.; Ferro, P.; Besagni, T.; Zappettini, A.; Calestani, G.; Marchi, E.; Ceroni, P.; Mosca, R. The Journal of Physical Chemistry C. 2015, 119, 21304-21313

58. Tanaka, K.; Takahashi, T.; Ban, T.; Kondo, T.; Uchida, K.; Miura, N. Solid State Communications. 2003, 127, 619-623

59. Pellet, N.; Teuscher, J.; Maier, J.; Grätzel, M. Chemistry of Materials. 2015, 27, 2181-2188

60. Stranks, S. D.; Eperon, G. E.; Grancini, G.; Menelaou, C.; Alcocer, M. J. P.; Leijtens, T.; Herz, L. M.; Petrozza, A.; Snaith, H. J. Science. 2013, 342, 341-344

61. Freppon, D. J.; Men, L.; Burkhow, S. J.; Petrich, J. W.; Vela, J.; Smith, E. A. Journal of Materials Chemistry C. 2017, 5, 118-126

62. Hu, F., Yin, C., Zhang, H., Sun, C., Yu, W.W., Zhang, C., Wang, X., Zhang, Y. and Xiao, M., Nano Letters. 2016. 16(10), 6425-6430

63. Rainò, G., Nedelcu, G., Protesescu, L., Bodnarchuk, M.I., Kovalenko, M.V., Mahrt, R.F., Stöferle, T. ACS Nano. 2016 10(2), 2485-2490. 